\title{
Laudable labs?
}

You can read much about the history of science and of architecture in the changing styles and materials used in the building of laboratories. It's a story of fashion, func tionality and financial constraints.

\section{Martin Kemp}

W e are all too familiar with the messy clutter of disparate laboratory buildings squeezed into congested university campuses. The lab is a major building type, yet we have come to expect little of it - other than as providing functional spaces which almost invariably prove to be inadequate as soon as they are occupied. It would be better if we cared more about the buildings' effects on our visual ambience.

All the larger structures have assumed their external appearance and internal configurations as the result of intense efforts by intelligent patrons and architects, and the older sites embody in microcosm the histories of nineteenth- and twentieth-century architecture. Two telling examples, cheek-byjowl on the Downing site at Cambridge University, are the School of Agriculture of 1909-10 (now housing the genetics department) and the Wellcome Wing built for the biochemistry department as an extension to the Sir William Dunn Building in 1961-63.

The agriculture school, designed by Arnold Mitchell, proudly proclaims its status through Edwardian rhetoric, above all in the two protruding bays topped by curved pediments, one of which once provided the main entrance. The sculptural adornment includes a proud array of heraldic shields (including the royal arms) and interlaced initials, whose significance has long since faded. In carved swags on either side of the upper windows, a series of agricultural tools - all romantic hand tools and no machinery — are suspend-

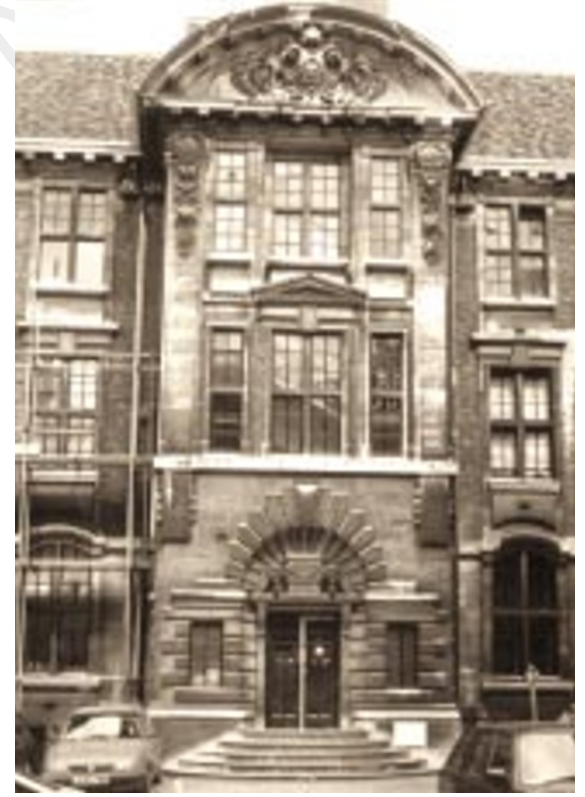

Making a statement: the School of Agriculture.

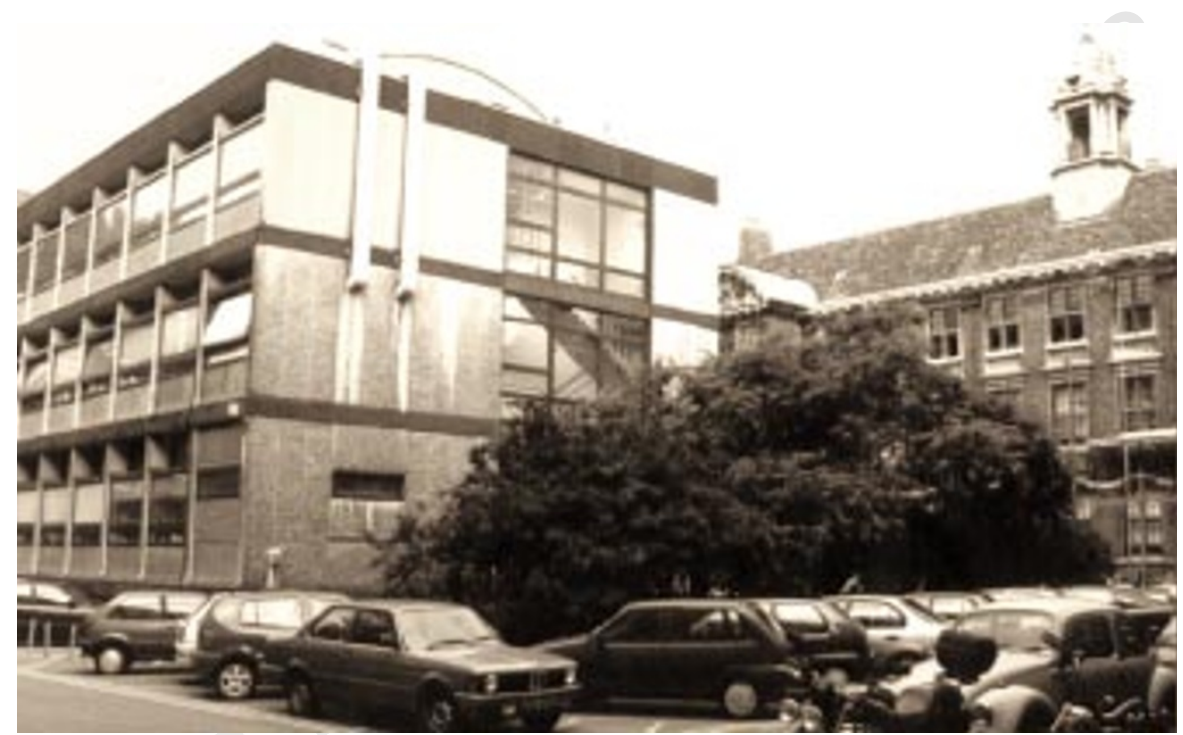

The Downing site at Cambridge: Arnold Mitchell's School of Agriculture (now the genetics department), 1909-10 (right), and the Wellcome Wing, 1961-63, designed by Roger Norton for Hammet and Norton.

ed from a sheaf of corn and a ram's head. The motto above the door reads, "Unto God Only Be the Honour and the Glory". The effort and expense devoted to such iconographical display was unthinkable only 50 years later.

The biochemistry wing exudes 1960s functionalism of mass production. Envisaged in principle in 1920, it was not until 1955 that the plans moved towards reality,

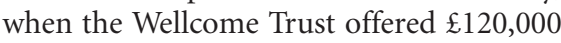
(US\$205,000). This was supplemented by $£ 200,000$ from the University Grants Committee in 1957, when Roger Norton was appointed as architect. Beset with the plan-
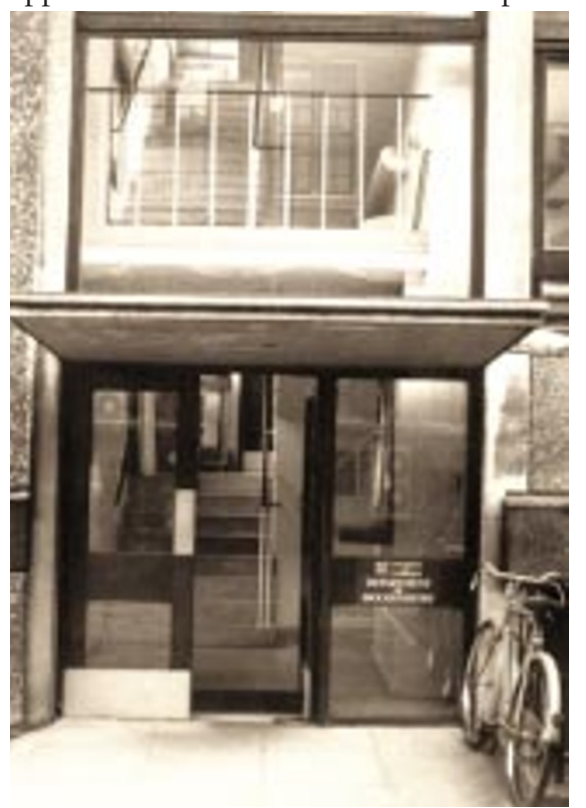

Modest and utilitarian: the Wellcome Wing. ning difficulties, delays and arguments that are endemic in committee-run projects, building work finally commenced in 1961.

The Wellcome Wing was a pioneering structure for the site. Built with precast concrete frames and hammered concrete columns, and clad in precast concrete slabs faced $w$ ith granite aggregate, it belonged very much to the brave new world. Its rhetoric spoke of function, struc tural integrity, delight in concrete and glass, and modular production - nicely in tune with biochemistry as the study of the modular engineering of organis ms. The prominent bic ycle shed speaks of utility, w hile the entrance modestly punc tuates the end bay w ith no more fuss than the windows above.

The building was well received. Nikolaus Pevsner, writing in his canonical The Buildings of England in 1970, hailed it as "clear, precise and well detailed ... probably the best building on the whole site". Pevsner, the author of Pioneers of Modern Design, was committed to the promotion of modernism.

Almost 40 years after its construction, distance has not lent enchantment to Norton's building. The School of Agriculture has mellowed nicely. The Wellcome Wing has simply aged. Its precast materials have weathered gracelessly. Or is it simply that inadequate distance lends unjustified disenchantment?

Martin Kemp is in the Department of the History of Art, University of Oxford, 35 Beaumont Street, Oxford OX12PG, UK. 